\title{
THE SACRED AND THE SCIENTIFIC: TRADITIONAL ECOLOGICAL KNOWLEDGE IN SIBERIAN RIVER CONSERVATION
}

\author{
Kheryn Klubnikin, ${ }^{1,5}$ Cynthia Annett, ${ }^{2,6}$ Maria Cherkasova, ${ }^{3}$ Michail Shishin, ${ }^{4}$ And Irina Fotieva ${ }^{4}$ \\ ${ }^{1}$ USDA Forest Service, Washington, D.C. 20250 USA \\ ${ }^{2}$ Center for Russian and East European Studies, University of Kansas, Lawrence, Kansas 66045 USA \\ ${ }^{3}$ Center for Independent Ecological Programs, Socio-Ecological Union, Box 67, Moscow, Russia 115407 \\ ${ }^{4}$ Fund for $21^{s t}$ Century Altai, Gorno-Altaisk, Altai Republic, Russia
}

\begin{abstract}
The Katun River originates in the steppe of the Altai Mountains in Siberia. One of the major headwaters of the Ob River, the Katun is considered central to the culture of the indigenous Altaians. The Katun Valley contains large numbers of important cultural sites, dating from the Neolithic and representing some of the earliest human settlement in Russia. Modern-day Altaians still observe traditional ceremonies honoring the river and springs throughout the watershed and utilize traditional ecological knowledge in their management of the land and water resources. Russian and international scientists have identified the Altai Mountains as a region of high plant diversity and endemism, and as important habitat for endangered species such as the snow leopard. The Katun River itself contains species of threatened and endangered fishes, and its headwaters are part of the unusual Mongolian ichthyofaunal province that is characterized by high levels of endemism. The same regions are considered by the Altaian people to be special or sacred and are recognized by Western scientists as having great value for conservation. During the era of perestroika, a hydroelectric dam was to be built on the Katun. The large dam, a vestige of the earlier Soviet plan for the Project of the Century, would have devastated significant agricultural, ecological, recreational, and cultural resources. The indigenous Altaian people would have lost much of their sacred and cultural landscape. The Katun dam project united indigenous people, well-known Siberian writers, and scientists in protest, which became so heated that it engaged the international community, with lasting effects on Russian society. The magnitude of the protest illustrates the importance of the Altai Mountain region to all of Russia. The active participation of indigenous Altaians reflected their traditional willingness to take action against political decisions that negatively impacted the environmental, cultural, and religious values of their homeland. Their involvement also reflected the new wave of awareness under perestroika that underscored a greater respect and autonomy for indigenous peoples in Russia.
\end{abstract}

Key words: Altai Republic; conservation; grassland; headwaters; Katun River; Ob River; pastoralist; perestroika; Russia; Siberian rivers; steppe; Traditional Ecological Knowledge.

\section{INTRODUCTION}

Siberia, along with the Amazon basin, is generally considered to be one of the only expansive and undeveloped open spaces remaining on earth, making it strategically important on a global scale (Bothe et al. 1993). At a size 1.5 times that of the United States, Siberia has two-thirds of the world's oil and gas reserves, as well as extensive deposits of most minerals

Manuscript received 25 March 1998; revised 8 June 1999; accepted 11 June 1999; final version received 8 July 1999. For reprints of this Invited Feature, see footnote 1, p. 1249.

${ }_{5}^{5}$ Present address: IUCN-The World Conservation Union, U.S. Office, 1630 Connecticut Ave. NW, Washington, D.C. 20009 USA.

${ }^{6}$ Author to whom correspondence should be addressed. Present address: Haskell Environmental Research Studies Center, Haskell Indian Nations University, Lawrence, Kansas 66046 USA. E-mail: cannett@gissrv.haskell.edu and rare elements, including gold and diamonds. Siberian taiga contains $54 \%$ of the world's coniferous forest and $31 \%$ of its temperate forest. In 1990, exploitation of resources from Siberia provided $50 \%$ of Russia's hard currency receipts (Bobrick 1992, Rosencranz 1993).

One of Siberia's most important strategic values is its role in the global water budget. When water from all of its lakes and rivers is added to that frozen in glaciers and permafrost, Siberia accounts for $80 \%$ of the world supply of fresh water. There are 53000 rivers across $10 \times 10^{6} \mathrm{~km}^{2}$. Three of the world's largest and longest rivers, the Ob, Lena, and Yenisei, have their origins in mountains of western Siberia; the runoff of each of these rivers is comparable to that of the Mississippi River. Lake Baikal, fed by 300 rivers, is the largest and deepest lake in the world, and alone is estimated to contain $20 \%$ of the 
world's fresh water (Knystautas 1987, Gleick 1993, Rosencranz 1993).

Siberia encompasses a rich and diverse mosaic of cultures and ethnic groups, including 30 distinct indigenous peoples who speak 35 languages, among which there are dialects that are not mutually understandable (Harris 1993, Forsyth 1994). Many of the indigenous people live in autonomous or semi-autonomous homelands. Although non-ethnic Russians comprise only $18.5 \%$ of the population of the Russian Federation, their identified homelands cover $53 \%$ of Russia's area (9049 $962 \mathrm{~km}^{2}$; roughly the area of the United States, including Alaska; Harris 1993). The large number of indigenous peoples in Siberia, combined with the diversity of cultural and religious beliefs, makes understanding the Traditional Ecological Knowledge of indigenous people very important for the development of economic and environmental policy in the former Soviet Union.

Conflicts with indigenous peoples over land and resources have arisen on many occasions during the almost 800 years of Russian settlement in Siberia (Forsyth 1994, Lincoln 1994). Many of the indigenous peoples were not readily converted to Orthodox Christianity, and conversions were often successful only with gifts of tribute, or at gunpoint (Grant 1993, Slezkine 1993). First the Orthodox Church, then the Soviets, sought to eradicate shamans; however, shamanism has been actively maintained until the present day in many areas of Siberia and many indigenous people have maintained animistic belief systems (Balzer 1997).

Siberian indigenous peoples were greatly affected during the Soviet period by the impact of huge dams constructed for hydroelectric production. Large numbers of people were forcibly relocated, villages were destroyed or flooded, and viable local economies were disrupted, significantly altering traditional values, beliefs, and lifestyles (Bobrick 1992, Rasputin 1996). Dams were a communist article of faith, dubbed "temples of kilowatts" by the poet Yevtushenko, and embodied power and modernization, as well as the noble and heroic conquest of nature (Bobrick 1992). Electrification was an important component of the Cold War in both the United States and the Soviet Union, and continues as a component of policy in both countries today.

The struggle to jump-start Russia's economy in the post-Soviet era is keeping projects of heroic scale alive in Siberia. A major new trend toward creating joint ventures between ministries and multinational corporations requires development of a large-scale industrial infrastructure, renewing the need for environmentally destructive projects (Rosencranz 1993). In recent years, however, the assertion of rights of indigenous peoples has played a pivotal role in massive protests over industrial facilities at Lake Baikal, oil and gas devel- opment on the Yamal Peninsula, and the development of hydroelectric dams on the great rivers of Siberia (Osherenko 1995).

The Katun River, in the headwaters of the $\mathrm{Ob}$, is one of the least impacted rivers in Siberia. It is also a river that is sacred to the Altaian people. In this paper, we discuss the importance of an alternative knowledge system in illuminating and articulating the value of natural resources and intrinsic ecosystem services to Altaian culture and identity as a people. We show evidence that both Traditional Knowledge and current practices of Altaian people have been a major influence on and motivation for the protest over construction of hydroelectric dams on the Katun River. We argue that the role of indigenous Altaian people in the defense of their cultural and natural landscape has been pivotal in Russian conservation history.

\section{The Altaian People and Their Environment}

\section{The Altaian people}

The Altaians are a Turkic people whose ethnic homeland lies in the Altai Mountains bordering Kazakstan, Mongolia, and China (Fig. 1), a region they have occupied for millennia (Forsyth 1994). Historically, the Altai region was part of emerging and collapsing tribal unions, khanates, and empires of the Scythians, Turks, Uigurs, Yenissey, Kirgiz, Kidans, Mongols, and Oirats (IUCN-World Conservation Union 1998). Landscape features and natural entities in the Altai Republic are central elements in the Altaian animistic spiritual belief system. In particular, lakes, rivers, springs, mountains, and other natural physical objects were understood to have spirit owners who needed to be acknowledged and honored. The shaman negotiated between the natural and the spiritual world on behalf of the community. Shamans have traditionally been important for their knowledge of folk medicine and the medicinal properties of native plants (Alekseev 1997, Balzer 1997, Forsyth 1994). Shamanic activities were documented in the 1980s and continue to be practiced in the region (Alekseev 1997; C. Annett and K. Klubnikin, personal observation).

Altaic shamans dealt with the spirits and deities of the upper, lower, and middle worlds; the earth was perceived as a disc in the middle, surrounded by primeval ocean supported on the back of an amphibian (Alekseev 1997). As ecologists, we find this particularly interesting, since amphibians are a notable element of healthy freshwater ecosystems, and one of the first harbingers of declines in health of aquatic ecosystems. In traditional Altai beliefs, the world was surrounded by the sky and the seasons, held in place by a tree. This image is still commonly used in the Altai Republic, a testament to the continuing importance of traditional beliefs. In a sense, animistic belief systems preclude subjugation and domination of the natural world, be- 


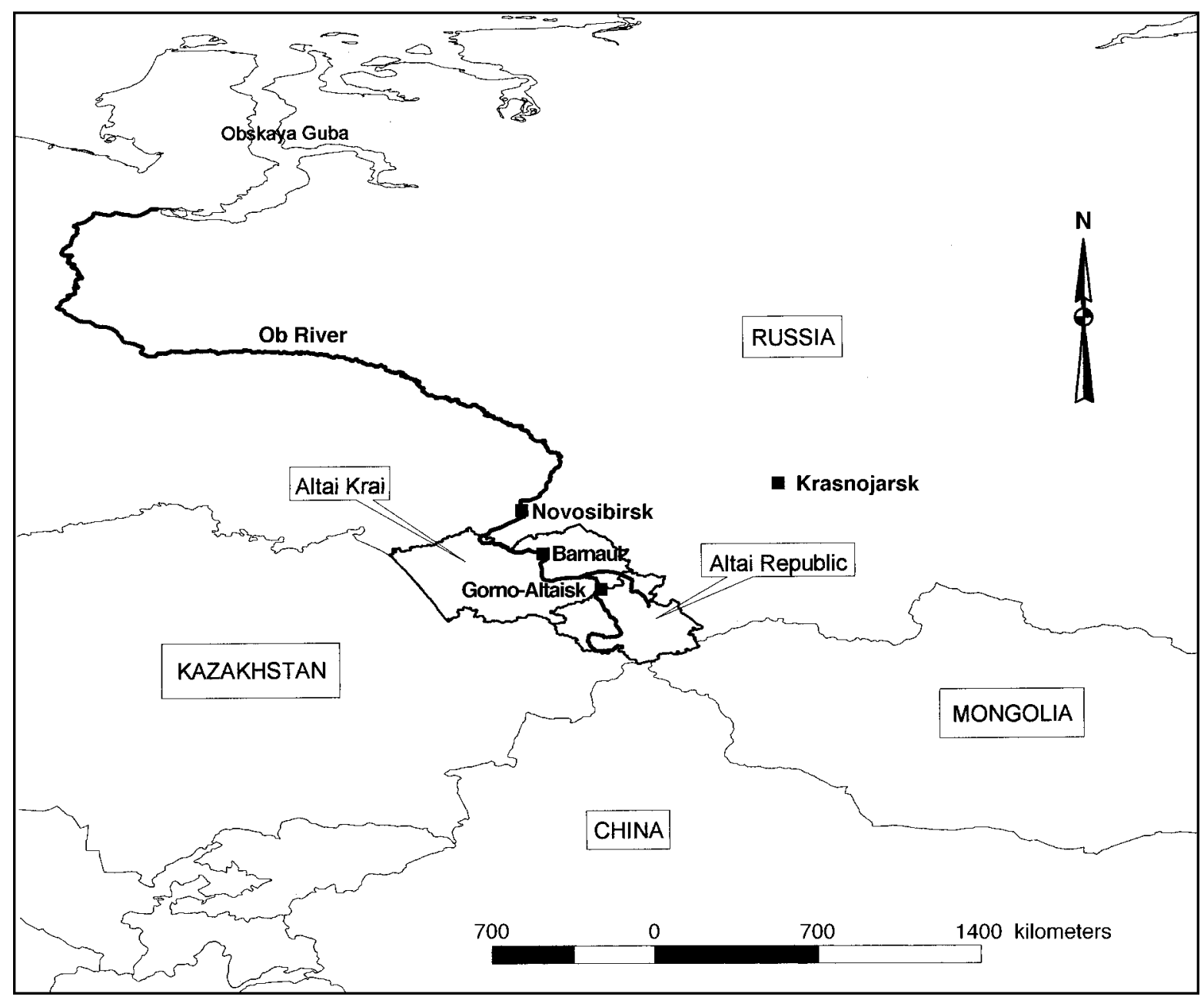

FIG 1. Location of the Altai Republic within the Russian Federation of States.

cause each person has a direct spiritual relationship with specific elements in the natural world.

The Altai Mountain region has played an important role in Russian history. For example, Ghengis Khan's mother was Altaian, and it is believed that he drew upon the strong organizational structure of the Altaian clans to support his military operations (Haltering 1987). After the Golden Horde fragmented, the Altaian people became part of the khanate of Dzungaria, caught between Russia and China. The resulting conflicts led in 1865 to the Altaians formally joining Russia to resolve the border dispute between Russia and China (Forsyth 1994, Lincoln 1994).

Russian settlement in the area that is now the Altai Republic was limited for a long time. Old Believers, fleeing religious persecution, settled there in small numbers during the 1600 s. Russians began to move into the region in increasingly large numbers with the completion of the Trans-Siberian Railway during the late 19th century. Pressure from Russian settlers, especially in the agricultural and mining regions to the north, caused several closely related Turkic tribes to retreat to the southern highlands of the Altai Republic. These tribes came together to form a cohesive group that is now known as Altaians. They have been able to maintain many aspects of their cultural and spiritual traditions that have been lost by indigenous peoples living in more heavily impacted regions of Siberia (Forsyth 1994).

The Altai Turkic peoples have long had a strong sense of ethnic identity, resulting in several periods of nationalist uprising. In 1905, they protested seizures of land and went to Moscow to appeal to the Duma for land rights. In 1917, they tried to form their own Duma. They were granted semi-autonomy in 1922. In response to pressure from Russian agriculture and industry in the northern region, a separatist movement arose in the mid-1920s. This evoked a strong response from the Soviet government, which intensified its anti-nomad policies and collectivization. The Altaians resisted, destroying over half of their cattle between the years 1929 and 1932 in protest (Forsyth 1994). In 1993, the region 
became the Altai Republic within the Russian Federation of States.

In recent decades, immigration of Russians has accelerated, especially to more urbanized areas in the northern forested region. The largest city in the Republic, Gorno-Altaisk, increased in population from 27534 in 1959 to 46436 in 1989. Currently, indigenous Altaians comprise $31 \%$ of the Republic's population, which accounts for $85 \%$ of all ethnic Altaians. Most $(85 \%)$ indigenous people identify the Altaian language as their native tongue. The ethnic homeland of the Altaians has a low population density, slightly more than two people per square kilometer. In contrast, just north of the Altai Republic is Siberia's most densely populated area, the industrial cities of Biisk, Barnaul, and Novosibirsk, with population densities an order of magnitude higher, about 25 people per square kilometer (Harris 1993).

\section{The Altai environment}

Altaians live in an ecotone between the taiga and the steppe. The lands of the Altai Republic are mountainous, with taiga making up $\sim 40 \%$ of the area. The rest of the Altai Republic is shortgrass steppe, especially in the southern districts currently occupied by the highest proportion of ethnic Altaians. Shortgrass steppe is characterized by low and unpredictable rainfall and well-drained sandy soils. In many of the high-altitude regions, the steppe is also underlain by permafrost. These factors, combined with the short growing season, make agriculture almost impossible in the south. Instead, horses, cattle, sheep, goats, and yaks (Bos grunniens) are herded in these regions, with yak commonly grazed in the high-altitude pastures. The soils of the semiarid steppe are fragile, requiring that herds be moved over great distances to avoid environmental degradation from overgrazing. Caring for herds means that Altaian families live a semi-nomadic lifestyle that takes them far from settled villages for part of each year (Annett and Klubnikin 1998).

The Altai Mountains encompass the most complete sequence of vegetation zones in Western Siberia and are viewed as a center of origin for montane vegetation of north Asia (Koropachinsky 1996). Montane tundra is found at the highest elevations, followed by steppe, with taiga, wetlands, and meadows at lower elevations. The vegetation of this region exhibits a high degree of endemism (12\%), higher than that found in either the Pyrenees or the Alps. The higher elevations also contain rare animals and are key areas for the conservation of endangered species. For example, the Gobi-Altai population of snow leopard (Uncia uncia) serves as a core source for dispersion of the species into southern Siberia, Mongolia, and Kazakstan (IUCN-World Conservation Union 1998).

Geographically, the Altai Mountains form the divide between the closed, arid watersheds of Inner Asia and the massive river drainages that flow northward through Siberia into the Arctic Ocean (Fig. 1). The Katun River, which originates entirely within the Altai Republic, is one of the most pristine, free-flowing stretches of river in Russia. The fish fauna of the high-mountain lakes at the headwaters of the Katun form a biotically complex pattern that is not yet well understood (Golubtsov et al. 1999). This watershed is part of the Mongolian biogeographic province, a region characterized by relict populations and endemic species and genera (Howes 1991). Populations of some endemic species have undergone evolutionary divergence, resulting in the formation of morphologically distinct populations and evolutionarily significant units (Golubtsov et al. 1999).

\section{Altaian Traditional Ecological Knowledge}

The authors have made many observations of the importance of water, particularly in the form of springs and rivers, in Altaian spiritual life; many rituals are still used to show respect to water. Original materials related to Altaian Traditional Ecological Knowledge (TEK) have been collected and interpreted over a period of many years by two of us (M. Shishin and I. Fotieva), who have primary research interests in the cultural anthropology of this region. Because most sources are obscure or unpublished, we provide a summary and illustrative examples of the role of TEK in modern Altaian culture.

The Katun River is considered a living being, and Altaians show respect by not throwing stones into the Katun. Special words are said whenever a river is crossed. Water is not taken from rivers at night, because this may upset the spirit associated with the river.

Spring water, called arzhan, is considered particularly important, and Altaians know the location of all of the springs in their homeland. Springs that are naturally high in minerals do not readily freeze, and are considered special. Sacred springs are curative, and people who are ill go to them regularly. The spring "agreeing" to help a sick visitor is signaled by the water turning the color of milk, but if the visitor's illness is incurable, a frog or snake will appear in the water. It is an important tradition for entire families to make special pilgrimages to springs, and in earlier times to live at a location for several weeks while performing rituals. An example of one of these rituals involved the family lining up with respect to the sun, with the father standing at the head of the line, and the family then requesting healing from the spirits associated with the spring. Altaians still make an effort to assume a properly respectful attitude when visiting springs, and leave offerings of pieces of light-colored cloth or coins. Signs, written in both the Altaian and Russian languages, have been posted at springs along the main roads to explain the importance of behaving reverently toward the springs. 
Two modern stories told by Altaians exemplify their ongoing belief in the spiritual powers of water:

One day, two men were on their way to a spring and were given a bundle of herbs by an elderly neighbor who asked them to place it in the spring. She explained that this would make a medicinal tea for her. The two men laughed, after all, they said, how could she tell whether they put her herbs into spring water, as opposed to any other water? It wasn't as if she had some kind of a test to tell where the water came from. When they arrived at the spring and threw the bundle of herbs into it, an odd thing happened; the bundle remained dry. As a result, they could not make the medicinal tea that the old woman had asked for. The moral of the story: nobody should laugh and joke when speaking to a sacred spring.

The other story concerns a man who carelessly threw a container for water into the car of his friends and asked them to fill it when they stopped at the spring. They filled the vessel with water and carefully closed it, but when they returned it was empty. The moral is: you must be reverent to the spirit of the spring.

Not only are springs and rivers sacred, but also the forested slopes that comprise their watersheds are protected, because the forest is considered a living being. Before hunting, for example, Altaians would "concentrate in their soul," asking the taiga to be kind to them. They then gave the taiga a present, most commonly a band of cloth tied to a tree. Altaians have a strong rule against taking more than is needed (i.e., herbs, firewood, fish), and even today, many Altaians will not agree to sell things gathered in the taiga. This is exemplified by the tradition that when a person perished in the taiga, the first supposition was that "he probably took too much.'

Although many plants were used for medicinal purposes, restraint was used in gathering them, because plants were thought to be a possession of the spirit of the place. By custom, the gatherers did not show the spirit that they were taking the plants, instead hiding them with a fur coat and bringing a sacrifice to the spirit of the place in thanks for the gathered plants. Ecologists might consider that Altaians engaged in a form of restoration ecology, because by restricting the amount that could be gathered in any one place, they allowed the plant populations to recover naturally.

Stone pine, also called cedar or kedr (Pinus sibiricus), is considered a sacred tree by Altaians, and is a good example of the use of plants for traditional purposes. Each part of the tree can be used. The resin was used to make a chewing gum that helped to clean teeth. Seedlings were boiled and the infusion was used to rinse out a person's eyes. Cedar nuts had many traditional uses; for example, chewing a handful of nuts was thought to heal throat ailments, and nuts were used to produce cedar "milk" and butter. Cedar were protected, so that only dead trees that were already dried out were used for firewood. Living trees were treated as living forest capital and were not cut unless absolutely necessary, and only when they could be taken without damaging wildlife or other aspects of the taiga ecosystem. A similar approach was incorporated into the management of the Kedrograd experiment, in which Russian scientists attempted to use non-timber forest products to develop a sustainable local economy in the Altai (Weiner 1999). Experience gained during the Kedrograd experiment eventually led to the involvement of these same scientists in the protests over dam development in the Altai.

\section{DAMS AND WESTERn SibERIA The Project of the Century}

Hydroelectric dams in the Altai Mountains were originally part of the Project of the Century, an unrealized turn-of-the-century plan that was later embraced by Stalin as he developed the support base needed for postwar industrialization of Siberia. The basic intent was to turn the great northward-flowing Siberian rivers and make them flow south (International Rivers Network 1990). Under this plan, a series of massive dams would harness energy, and new river channels would shunt water for irrigation into the arid reaches of Central Asia (Clarke 1993). Although never fully realized by Stalin, the project gained importance under Brezhnev (Lincoln 1994). Electrification of Siberia was viewed by modern Soviets as a major component of successful industrialization and competition with the West. Twenty-three dams were built on the Yenisei River alone, flooding entire river valleys and causing the relocation of many villages, deeply affecting the indigenous peoples of the region (Bobrick 1992).

Grassroots opposition to river development proposals surfaced in 1982 in Russia. The potential impacts of the projects were predicted to be so extensive as to change the climate of northern Europe, a fact that brought Scandinavia into the protest. A number of wellknown Siberian authors openly questioned government plans to construct huge engineering projects on the rivers of Siberia, and were pivotal in focusing national attention on the problem. Among them, the distinguished writer Valentin Rasputin had gained international recognition for his books and essays portraying the social costs that resulted from flooding of his own village by the Bratsk Dam on the Angara River (Rasputin 1979, 1989, 1996), which displaced 70000 people before it was finally completed (Parthe 1979, Mikkelson and Winchell 1989, Winchell and Mikkelson 1996).

Gorbachev responded to public pressure by establishing a special commission, drawn from five branches of the USSR Academy of Sciences, to review the entirety of the Project of the Century. The Commission was the first successful, independent, technical review of government projects in modern Russia. The Com- 
mission issued a substantively negative report, with the result that the Communist Party Congress dropped the Project of the Century from the 1986 planning cycle. The Ministry of Reclamation and Water Management continued, however, to expend funds to initiate construction on individual projects. This resulted in an even greater public outcry, which led to a comprehensive legal review and subsequent termination of the overall project in 1988. Rosencranz (1993) asserts that this enormous public environmental protest was central to changes in Russia's legislative process, helped to forge the link between law and politics, and was central to perestroika.

Efforts to construct hydroelectric dams in the Altai Mountains were inexplicably continued after the Project of the Century was terminated, triggering the formation of yet another wave of opposition that became international in scope. The Katun Dam protest itself played a crucial role in the pro-democracy movement of the 1980s in Eastern Europe (McCulley 1996:282). Participation by the indigenous people of the Altai Mountains in the backlash over the Katun Dam highlighted the traditional relationship between Altaians and rivers.

\section{Dams on the upper $\mathrm{Ob}$ River}

The sacred river of the Altaians, the Katun, flows northward from Mount Belukha, the highest mountain in Siberia, to its confluence with the Biya River, where together they form the $\mathrm{Ob}$. When traced from the headwaters of the Katun (as opposed to the Irtysh) to the Arctic Sea, the $\mathrm{Ob}$ is the 13th longest river in the world $(4338 \mathrm{~km})$. The $\mathrm{Ob}$ drains a huge area $\left(2.5 \times 10^{6} \mathrm{~km}^{2}\right)$, including Siberia's most populated region, the industrial centers of Biisk, Barnaul, and Novosibirsk, as well as areas developed for extraction of petroleum reserves, which heavily impact water quality (Gerloff 1993).

The Ob River is dammed at Novosibirsk to create a hydroelectric power station. The reservoir that forms the "Ob Sea" is the only major impoundment on the $\mathrm{Ob}$, Katun, or Biya Rivers, and has flooded some of the region's most productive agricultural land (Stewart 1992). The dam at Novosibirsk has decreased the volume of water flowing through the huge areas of wetlands on the middle reaches of the Ob. Originally comprising $25 \%$ of the water flowing down the $\mathrm{Ob}$, these wetlands formed important spawning and foraging habitat for many fish species, including 18 commercially exploited species. Reduction in flow caused a sharp decline in recruitment, reducing fishing yields from $6000-7000 \mathrm{Mg}$ (metric tons) to an annual harvest of only $1000 \mathrm{Mg}$ (Babyueva et al. 1994). The hydroelectric stations had a significant negative impact on the large fishes that historically moved upriver from the $\mathrm{Ob}$ into the Katun and Biya Rivers. For example, the Novosibirsk and Ust-Kamenogorsk power stations cut off $40 \%$ of the spawning sites used by sturgeon and
$80 \%$ of spawning grounds used by nelma (Stenodus leucicthys nelma), which is now listed in the Red Book of the Altai Republic (Babyueva et al. 1994).

The environmental impacts caused by the dam that formed the "Ob Sea" extended upriver at least as far as the mid-reaches of the Katun in the Altai Republic. There was good reason, therefore, to expect the proposed projects on the Katun to have significant negative impacts on the river ecosystem.

\section{Traditional Ecological Knowledge and the dam on the Katun}

Even though the Project of the Century had been terminated, the Ministry of Energy continued in the late 1980 s to review plans to construct dams along 688 $\mathrm{km}$ of the Katun River and its major tributaries. If completed, the main dam would have stood $180 \mathrm{~m}$ high. The original intent of this project was to generate 1.9 $\times 10^{6} \mathrm{kw}$ of electricity, a large portion of which is thought to have been destined for the Siberia Joint Power System and not for local consumption (Statement of the State Commission of Experts, 25 December 1992). Some suspected that the dam project was actually being proposed as a way to provide jobs for workers displaced from other terminated construction projects (Rasputin 1996).

The impoundments formed by the project would have flooded 5800 ha of the Altai Republic's prime agricultural bottomlands. Because most of the Altai Republic is either steep, mountainous terrain or semiarid steppe, relatively little land is available for agriculture; $<2 \%$ of the 9294000 -ha area of the Republic is considered arable land. This means that the reservoirs resulting from impoundment by hydroelectric dams would have covered almost $5 \%$ of the already inadequate amount of arable land in the Altai Republic.

Villages in the Altai Republic are typical of remote regions of Siberia, lacking indoor plumbing or wastewater treatment. Residents must carry water for domestic use, making it necessary for them to build their homes close to streams or lakes. In semiarid regions, riparian forests are the main source of wood for fuel and building materials, are important as habitat for wildlife, and supply many plants used for food and traditional medicines. Proposed hydroelectric dams would have flooded 812 ha of riparian forest, requiring villages to be moved to less favorable sites, which is known to be widely disruptive to people in Siberia (Rasputin 1989).

The Altai Mountains have been exploited for silver, gold, and other minerals for centuries, and were the site of some of the Demidov copper and silver mines (Bobrick 1992, Lincoln 1994). Elevated mercury levels have been found in the Saransinsky mercury zone of the Kuznetsky-Altai ore belt, with elevated levels of mercury detected in the Katun and Ob Rivers (Coquery et al. 1995, Sukhenko 1995). Entire lakes in the Altai 
Mountains have been poisoned by mercury (Lincoln 1994). Russian scientists expressed considerable concern over the potential build up of mercury in the reservoirs that would have been formed behind the hydroelectric dams on the Katun and its tributaries. Elevated mercury levels would have endangered village water supplies and potentially threatened water supplies used by the densely populated urban zone downstream, to the north of the Republic.

Major tributaries of the Katun flow through the highaltitude summer pastures used by Altaian herders. Although the headwaters contain only a few species of fish, the fish biomass is relatively high in the lakes that feed the rivers (Babyueva et al. 1994). In particular, fishing for grayling (Thymallus arcticus) and osman (Oreoleuciscus spp.) supplements the diet of families during their stay in summer camps (C. Annett, personal observation). The indigenous people can distinguish fish species and morphotypes by habitat and characteristics such as oiliness of flesh and size of eyes; e.g., Oreoleuciscus from Lake Karakol are distinguished by local fishermen for their high gastronomic quality and are called by a special name, "sultanka." The validity of these observations is reflected in the results of scientific study of the systematics of Oreoleuciscus, which found that the fish from Lake Karakol could be separated out from other conspecific populations in multivariate space, based on morphometric characteristics (Golubtsov et al. 1999).

Construction on the Katun Dam site, begun in 1982, had been temporarily halted because of controversies raised during earlier public protests. Organizers of the anti-dam movement collected over 150000 signatures on petitions against the proposed dam. Opposition to the dam was included in a formal agreement between environmentalists from the United States and USSR, including Friends of the Earth and the National Wildlife Federation (International Rivers Network 1990). Over 100 publications were devoted to the problems associated with construction of the hydroelectric facility. Media coverage was unprecedented for a public protest during the Soviet period, with coverage in newspapers, television, and radio broadcasts both domestically and internationally. The extent of coverage allowed the public to become informed about the issues on both sides and, for the first time, to discuss at length alternatives to a government project.

Expert testimony presented during the protest stressed the cultural significance of the Katun River and the lands that would be submerged beneath the reservoirs. Archaeological surveys of the sites found over 2100 burial mounds, 14 ancient settlements, and 20 sites with petroglyphs that would be destroyed by impounding the Katun. Some of the burial mounds dated back over 1300 years, and the settlements were dated to the Bronze and Early Iron Age. The most ancient petroglyphs are located at the proposed dam site itself, an area that is particularly important to Altaian beliefs because it is featured in origin stories.

Organizers of the protest movement included scientists of Altaian ancestry and members of the USSR Academy of Sciences, many of whom had done extensive studies in the Altai Republic and who had close ties to Altaian families. This gave them a deep understanding of traditional Altaian beliefs and, in particular, the importance of Mount Belukha and the Katun River in the spiritual life of the indigenous people. The belief that mountains, land, and water are part of the living world inhabited by Altaian people, deserving of respect and capable of anger, infused the choice of words used to describe the concerns of Altaians over the construction of the proposed Katun dam.

Concerns over water quality went well beyond what would be expected based on the known health risks from mercury and other pollutants, and instead focused on the concept of treating water in a respectful fashion. The need to maintain environmental purity, especially the purity of water, was given as a higher priority by many of the people who provided testimony at public hearings than either employment or material wealth. In a letter to Mikhail Gorbachev that was signed by the indigenous inhabitants of the Altai Mountains, the Katun River was described as "a blood artery that is essential to the survival of Altaian people." Over 4000 inhabitants of the Altai Mountains signed an appeal that called for recognition of the "unique riches of the Altai Mountains," and stated that "the veritable pearl of Siberia must become the property of all of the people (of Russia) and the source of a new humanistic relationship between nature and culture."

A letter from the people of Kazpy village quoted Valentin Rasputin as saying that the Altai Republic is "one of the most beautiful corners of our motherland, one of the most ecologically pure places on our planet." They went on to say that Gorny-Altai (the Altai Republic) is easily wounded. Her "natural balance is seriously undermined by the barbaric cutting down of forests" and "we turn to those for whom Gorny-Altai is dear, and for her nature and her native people, the Altaians, we ask for them to defend this pearl."

Another letter described how clear-cutting a forested region decimated the traditional culture of another Turkic tribe, the Shors. Known originally as "blacksmith Tatars," the Shors were subjected to rapid industrialization of their homeland in the Kuzbass region, north of the Altai Republic, which eventually led to the abolishment of the Shor National District in 1939 (Forsyth 1994). The writer of the letter equated the loss of forest with the loss of tribal identity, and feared that the same would happen to other tribes if they lost the Katun to impoundment.

Concerns were also expressed by Altaians about the conservation of plants that are important for traditional medicines, as well as specific plants that are used in 
shamanic rituals (discussions of Altaian shamanism may be found in Eliade 1964, Alekseev 1997). Many important species are only found in bottomlands and riparian forests, areas that would be destroyed by flooding from the hydroelectric facilities. Indigenous knowledge of plant biodiversity and the cultivation of medicinal herbs are major areas of research at the Central Siberian Botanical Gardens, part of the Russian Academy of Sciences (Koropachinsky and Sedelnikov 1994, Koropachinsky 1996), and provide examples of how scientists have learned about native plants through the use of the Traditional Ecological Knowledge of the indigenous Altaians.

Altaians not only expressed their cultural beliefs in their protest, but also presented many alternative uses for the headwater regions, including cultivation and harvesting of ecologically appropriate crops such as pine nuts, beekeeping and organic honey production, small-scale dairy operations that employ women, and traditional methods of rotating herds in numbers that could be supported without serious environmental degradation. The long-held belief by Altaians and Russians alike, that the relatively unpolluted Altai Republic is important for restoring health, was stressed. This is of particular importance for Russians, who have been subjected to a tremendous amount of media coverage in recent years about serious health problems caused by environmental degradation during the Soviet period (Goldman 1992, Ziegler 1992). Potential recreational uses, traditional festivals and crafts, scenic beauty, ecotourism, and river rafting were all recognized as being of importance for a locally viable economy. Together with scientists and others in the protest, Altaians called for the establishment of a new national park around the Katun headwaters. This was accomplished in 1991. In 1998, the area was approved for inclusion in the UNESCO system of World Heritage sites, and it was recently included in the World Wildlife Fund's "Global 200" campaign of important ecosystems.

Remarkably, the protest over the Katun dam involved scientists all the way from Novosibirsk to Moscow and Leningrad (St. Petersburg). Because of the formidable amount of expertise that they encompassed, the SocioEcological Union was chartered by the Department of Justice in 1992 as Russia's first nongovernmental group. Considered an umbrella organization, the SEU organized three independent scientific reviews that were pivotal in stopping the Katun dam. Many of the founding members of the SEU were student $d r u$ zhina (nature activists and advocates) in the 1950s, a movement that arose from a long-standing Russian folk tradition of nature protection (Hubbs 1993, Weiner 1999). As students, they tried to stop illegal wildlife trade, enforce nature laws, and fight against water pollution, and many were involved in the Kedrograd experiment. By the 1980s most of the students had become professors and academics, and were able to cap- italize upon the far-flung network of smaller, decentralized environmental organizations across Russia to mobilize participation in the protests of the 1980s (Weiner 1999).

\section{Rights of indigenous peoples and current environmental conflicts}

Public awareness about native rights and conditions in Russia was catalyzed during the period of perestroika in the 1980s, leading to the development of an Association of Peoples of the North in 1989, and the recognition of the need for a more active role for indigenous peoples in the government (Forsyth 1994, Slezkine 1994). The first Conference of the Small Peoples of the North took place in 1990, resulting in increased political momentum for representation in the government and the formation of new autonomous areas (IWGIA 1990). In May 1991, the Supreme Soviet assembled a subcommission with deputies representing all minority peoples. As reforms were proposed, native ecological interests were considered a priority. Significantly, this included acknowledging that land was not simply a possession for indigenous people, but a source of spiritual meaning, and personal and group identity (Has and Zaochnaia 1993).

There is a growing awareness throughout the world of the need for indigenous participation in economic development and environmental management, as well as a great deal of concern over the erosion of indigenous knowledge (Barsh 1997). The United Nations Conference on Environment and Development in 1992 recognized the rights of indigenous peoples to participate in issues concerning the environment and economic development. The rights of indigenous peoples were extensively discussed in Rio and influenced the development of Agenda 21, which supported the International Labor Organization Indigenous and Tribal Peoples Convention (Number 169, the draft universal declaration on indigenous rights, and the International Year for the World's Indigenous People; Grubb et al. 1993).

It is noteworthy that indigenous peoples were not originally involved in the negotiation of the Biodiversity Convention (Schulthess 1994). There is now a growing concern about the lack of opportunity for indigenous participation in international environmental forums (Chakma 1994, Jacanamejoy 1994). As a consequence, the United Nations Convention to Combat Desertification openly acknowledged the contributions and importance of indigenous knowledge in its second Conference of Parties in Dakar, Senegal in 1998, and the United Nations Commission on Human Rights has been considering the formation of a permanent forum to provide indigenous peoples more centralized and formal involvement in the work of the United Nations (UNNGLS 1998).

Traditional Ecological Knowledge is accrued over a 
long period of time through a spatial, emotional, and spiritual connection with a specific local environment (Graber 1976, Tuan 1977, Pierotti and Wildcat 1997). Concerns of local indigenous and traditional peoples often have been overlooked because international development has relied solely on Western science and technology. Tragic results can be caused by the failure to develop institutions that internalize environmental and social costs of development. In particular, major controversies can be caused by the lack of involvement of the indigenous peoples affected, not properly assigning indigenous rights and royalties to resources, and not investigating alternative, small-scale sustainable development that builds upon the strength of local economies and traditions (Osherenko 1995).

As an example, a recent study using satellite imagery has shown that grassland regions of Inner Asia (which, in addition to the Altai, includes the Russian Republics of Tuva, Chita, and Buryatia, parts of China, and Mongolia) were severely degraded by the imposition of government policies to increase livestock production while destroying nomadic practices (Sneath 1998). The change to mechanized mixed farming during the Soviet period of collectivization resulted in severe and lasting degradation of dry grasslands. Likewise, significant degradation was caused by the attempt made by the Chinese to plow the virgin steppe. In contrast, retention of the relatively mobile system of traditional pastoral land use in Mongolia and Tuva has had much less of a negative impact on the commonly owned pastures (Sneath 1998).

Barsh (1997) argues that indigenous knowledge is essentially scientific because it is gathered through methods that are empirical, experimental, and systematic, and therefore it is not necessary that there be an inherent contradiction between the mythological and the scientific. In fact, Western science, established as a formalized knowledge system largely during the industrial revolution, is seen by some as considering and defining questions in a narrow and socially naive way (Charland 1996). In contrast, Traditional Knowledge can supply the nonlinear and pluralistic perspectives that increasingly are being called for to provide a socially relevant context for development projects (Chemilinsky 1991, Ludwig et al. 1993, Lele and Norgaard 1996, IUCN Inter-Commission Task Force on Indigenous Peoples 1997).

The environmental battles in the Altai Republic are still ongoing, including renewed interest in developing hydroelectric power within the Katun River system. The current economic crisis in Russia, combined with changing policies due to the evolving legal and governmental structure, makes it impossible to predict the future of river conservation in Siberia. The Katun is one of the most pristine watersheds in Russia, and because it is entirely within the jurisdiction of a single Republic, it provides an excellent opportunity to invoke
Traditional Knowledge in natural resource planning. The Altai Republic has the potential to achieve an appropriate scale of sustainable development, as called for in public hearings during the debate over the Soviet plan to dam the Katun. As stated by Clark (1995), a viable concept of sustainable natural resource management and economic development, by necessity, creates a synergy between the application of ecological principles and social equity, and must rely on verifiable standards of performance. Traditional Ecological Knowledge can inform the modern political arena in Russia, and work in conjunction with scientific knowledge to effect protection of cultural and natural entities.

\section{ACKNOWLEDGMENTS}

The authors extend their thanks to the government of the Altai Republic for the assistance of many people in our many travels within the region. V. P. Sedelnikov, Deputy Director of the Central Siberian Botanical Garden, A. Golubtsov of the Russian Academy of Sciences, Moscow, and N. P. Malkov of the University of Gorno-Altaisk have provided us with invaluable assistance. We wish to thank our colleagues in the Altai Republic, especially N. Shaktinova. N. Tanberg translated unpublished materials. D. Siegel-Causey, J. Mikkelson, R. Pierotti, and D. Wildcat have provided help with background material and comments on various drafts. Maps were designed by C. J. Cŏté, International Liaison for Environmental Systems Research Institute, Vienna, Virginia, USA. We also thank E. Fernandez, Senior Advisor for Social Policy for IUCN-The World Conservation Union, for his contributions and comments. This work was partially supported by the National Science Foundation (D62-9450181, OPP9725155), the National Research Council Office for Eurasia, The National Academy of Sciences/Russian Academy of Sciences Young Investigators in Biodiversity Program, Ecologically Sustainable Development, Inc., and the USDA Forest Service, Research and Development.

\section{Literature Cited}

Alekseev, N. A. 1997. Shamans and their religious practices. Pages 49-109 in M. Balzer, editor. Shamanic worlds: Rituals and lore of Central Asia. North Castle Books, New York, New York, USA.

Annett, C. A., and Kh. Klubnikin. 1998. Observations of grassland aquatic communities in steppes of North America and Western Siberia. Ecological Congress International Journal 1:13-22.

Babyueva, B. V., V. G. Mordkovich, Yu. S. Rankin, V. I. Faleyev, A. Yu. Kharitov, and Yu. G. Shevtsov. 1994. Zoological resources of Siberia. Siberian Journal of Ecology 1:45-63.

Balzer, M. M. 1997. Introduction. Pages xiii-xxxii in M. M. Balzer, editor. Shamanic worlds: rituals and lore of Central Asia. North Castle Books, New York, New York, USA.

Barsh, R. L. 1997. Forests, indigenous people, and biodiversity. Global Biodiversity 7:20-23.

Bobrick, B. 1992. East of the Sun: the epic conquest and tragic history of Siberia. Henry Holt, New York, New York, USA.

Bothe, M., T. Kurzidem, and C. Schmidt. 1993. Introduction. Pages ix-xiii in M. Bothe, T. Kurzidem, and C. Schmidt, editors. Amazonia and Siberia: legal aspects of the preservation of environment and development in the last open spaces. Graham and Trotman/Martinus Nijhoff, London, UK.

Chakma, K. 1994. Development, environment and indigenous women in the Chittagong Hill tracts of Bangladesh. 
Pages 233-238 in A. F. Krattiger, J. A. MacNeely, W. H. Lesser, K. Miller, Y. St. Hill, and R. Senanayake, editors. Widening perspectives on biodiversity. IUCN-The World Conservation Union and the International Academy of the Environment, Geneva, Switzerland.

Charland, J. W. 1996. The "problem-isolation paradigm" in resource management. Journal of Forestry 94:6-9.

Chemilinsky, E. 1991. On social science's contribution to government decision making. Science 254:226-231.

Clark, J. G. 1995. Economic development versus sustainable societies: reflections on the players in a crucial contest. Annual Review of Ecology and Systematics 26:225-248.

Clarke, R. 1993. Water: the international crisis. MIT Press, Cambridge, Massachusetts, USA.

Coquery, M., D. Cossa, and J. M. Martin. 1995. The distribution of dissolved and particulate mercury in three $\mathrm{Si}$ berian estuaries and adjacent Arctic coastal waters. Water, Air and Soil Pollution 80:653-665.

Eliade, M. 1964. Shamanism: archaic techniques of ecstasy. Princeton University Press, Princeton, New Jersey, USA.

Forsyth, J. 1994. A history of the peoples of Siberia: Russia's North Asian colony 1581-1990. Cambridge University Press, Cambridge, UK.

Gerloff, J. U. 1993. Ecological conditions for further development of environmental policy and law in Amazonia and Siberia. Pages 28-33 in M. Bothe, T. Kurzidem, and C. Schmidt, editors. Amazonia and Siberia: legal aspects of the preservation of environment and development in the last open spaces. Graham and Trotman/Martinus Nijhoff, London, UK.

Gleick, P. H. 1993. Water in crisis: a guide to the world's freshwater resources. Oxford University Press, New York, New York, USA.

Goldman, M. I. 1992. Environmentalism and nationalism: an unlikely twist in an unlikely direction. Pages 1-10 in J. M. Stewart, editor. The Soviet environment: problems, policies, and politics. Cambridge University Press, Cambridge, UK.

Golubtsov, A. S., P. B. Berendzen, and C. A. Annett. 1999. Morphological variation and taxonomic status of the Altai osman Oreoleuciscus (Pisces: Cyprinidae) from the upper reaches of the $\mathrm{Ob}$ River system. Journal of Fish Biology 54:878-899.

Graber, L. 1976. Wilderness as a sacred space. Monograph Series Number 8. American Association of Geographers. Washington, D.C., USA.

Grant, B. 1993. Siberia hot and cold: reconstructing the image of Siberian indigenous peoples. Pages 227-254 in G. Diment and Y. Slezkine, editors. Between heaven and hell: the myth of Siberia in Russian culture. St. Martins Press, New York, New York, USA.

Grubb, M., M. Koch, A. Munson, F. Sullivan, and K. Thomson. 1993. The earth summit agreements: a guide and assessment. Earthscan Publications, London, UK.

Haltering, C. J. 1987. Russia and the golden horde: the Mongol impact on medieval Russian history. Indiana University Press, Bloomington, Indiana, USA.

Harris, C. D. 1993. A geographic analysis of non-Russian minorities in Russia and its ethnic homelands. Post-Soviet Geography 34:543-597.

Has, M., and T. Zaochnaia. 1993. The present situation of indigenous peoples in Siberia. Pages 269-283 in M. Bothe, T. Kurzidem, and C. Schmidt, editors. Amazonia and Siberia: legal aspects of the preservation of environment and development in the last open spaces. Graham and Trotman/ Martinus Nijhoff, London, UK.

Howes, G. J. 1991. Systematics and biogeography: an overview. Pages 1-33 in I. J. Winfield and J. S. Nelson, editors. Cyprinid fishes: systematics, biology and exploitation. Chapman and Hall, London, UK.
Hubbs, J. 1993. Mother Russia: the feminine myth in Russian culture. Indiana University Press, Bloomington, Indiana, USA.

International Rivers Network. 1990. International opposition to Katun dam. World Rivers Review 5:9, 11.

IUCN-World Conservation Union. 1998. Documentation on World Heritage Properties (natural). World Heritage Committee. Twenty-second Session. 30 November-5 December 1998, Kyoto, Japan. Gland, Switzerland.

IUCN Inter-Commission Task Force on Indigenous Peoples 1997. Indigenous peoples and sustainability: cases and actions. International Books, Utrecht, The Netherlands.

IWGIA (International Workgroup for Indigenous Affairs). 1990. Indigenous peoples of the Soviet north. Document number 67. International Secretariat for Indigenous Affairs. Copenhagen, Denmark.

Jacanamejoy, G. M. 1994. Community participation in the conservation of biodiversity. Pages 229-232 in A. F. Krattiger, J. A. MacNeely, W. H. Lesser, K. Miller, Y. St. Hill, and R. Senanayake, editors. Widening perspectives on biodiversity. IUCN-The World Conservation Union and the International Academy of the Environment, Geneva, Switzerland.

Knystautas, A. 1987. The natural history of the USSR. MacGraw-Hill, New York, New York, USA.

Koropachinsky, I. Y. 1996. Green book of Siberia: rare and requiring protection plant communities. Nauka (Siberian Publishing Firm RAS), Novosibirsk, Russia.

Koropachinsky, I. Y., and V. P Sedelnikov. 1994. Plant resources of Siberia: their contemporary state and protection. Siberian Journal of Ecology 1:15-25.

Lele, S., and R. V. Norgaard. 1996. Sustainability and the scientist's burden. Conservation Biology 10:354-365.

Lincoln, W. B. 1994. The conquest of a continent: Siberia and the Russians. Random House, New York, New York, USA.

Ludwig, D., R. Hilborn, and C. Waters. 1993. Uncertainty, resource exploitation and conservation: lessons from history. Science 260: $17-20$.

McCulley, P. 1996. Silenced rivers; the ecology and politics of large dams. Zed Books, London, UK.

Mikkelson, G., and M. Winchell. 1989. Valentin Rasputin and his Siberia. Introduction. Pages ix-xxii in V. Rasputin. Siberia on fire. Northern Illinois University Press, DeKalb, Illinois, USA.

Osherenko, G. 1995. Indigenous political and property rights and economic/environmental reform in Northwest Siberia. Post-Soviet Geography 36:225-237.

Parthe, K. 1979. Foreword: Master of the island. Pages viixxiii in V. Rasputin. Farewell to Matyora. Northwest University Press, Evanston, Illinois, USA.

Pierotti, R., and D. Wildcat. 1997. The science of ecology and Native American traditions. Winds of Change (Journal of the American Indian Science and Engineering Society) 12:(4)94-98.

Rasputin, V. 1979. Farewell to Matyora. Northwestern University Press, Evanston, Illinois, USA.

Rasputin, V. 1989. Siberia on fire. Northern Illinois University Press, DeKalb, Illinois, USA.

Rasputin, V. 1996. Siberia, Siberia. Northwestern University Press, Evanston, Illinois, USA.

Rosencranz, A. 1993. Preserving the environment of Siberia Pages 78-88 in M. Bothe, T. Kurzidem, and C. Schmidt, editors. Amazonia and Siberia: legal aspects of the preservation of the environment and development in the last open spaces. Graham and Trotman/Martinus Nijhoff, London, UK.

Schulthess, B. 1994. The Earth Council's role in strengthening indigenous peoples' participation in implementing the Convention on Biodiversity. Pages 225-227 in A. F 
Krattiger, J. A. MacNeely, W. H. Lesser, K. Miller, Y. St. Hill, and R. Senanayake, editors. Widening perspectives on biodiversity. IUCN-The World Conservation Union and the International Academy of the Environment, Geneva, Switzerland.

Slezkine, Y. 1993. Savage Christians or unorthodox Russians? The missionary dilemma in Siberia. Pages 15-32 in G. Diment and Y. Slezkine, editors. Between heaven and hell: the myth of Siberia in Russian culture. St. Martins Press, New York, New York, USA.

Slezkine, Y. 1994. Arctic mirrors: Russia and small peoples of the North. Cornell University Press, Ithaca, New York, USA.

Sneath, D. 1998. State policy and pasture degradation in Inner Asia. Science 281:1147-1148.

Stewart, J. M. 1992. Air and water problems beyond the Urals. Pages 223-237 in J. M. Stewart, editor. The Soviet environment: problems, policies and politics. Cambridge University Press, Cambridge, UK.
Sukhenko, S. A. 1995. Relation between mercury concentration and water discharge in the Katun River of Siberia. Marine and Freshwater Research 46:245-251.

Tuan, Yi-Fu. 1977. Space and place: the perspective of experience. University of Minnesota Press, Minneapolis, Minnesota, USA.

UNNGLS (United Nations Non-Governmental Liaison Service). 1998. The United Nations and indigenous peoples. NGLS Roundup. December 1998-January 1999. United Nations, New York, New York, USA.

Weiner, D. R. 1999. A little corner of freedom: Russian nature protection from Stalin to Gorbachev. University of California Press, Berkeley, California, USA.

Winchell, M., and G. Mikkelson. 1996. Translator's introduction. Pages 1-31 in V. Rasputin. Siberia, Siberia. Northwestern University Press, Evanston, Illinois, USA.

Ziegler, C. E. 1992. Political participation, nationalism and environmental politics in the USSR. Pages 24-39 in J. M. Stewart, editor. The Soviet environment: problems, policies and politics. Cambridge University Press, Cambridge, UK. 